medRxiv preprint doi: https://doi.org/10.1101/2020.11.11.20214247; this version posted November 13,2020 . The copyright holder for this preprint (which was not certified by peer review) is the author/funder, who has granted medRxiv a license to display the preprint in It is made available under a CC-BY-NC-ND 4.0 International license .

\title{
Children with familial hypercholesterolemia display changes in LDL and HDL function: a cross-sectional study
}

Jacob J. Christensen, $\mathrm{PhD}^{1,2}$, Ingunn Narverud, $\mathrm{PhD}^{1,2}$, Maija Ruuth, $\mathrm{PhD}^{3,4}$, Martin Heier, $\mathrm{MD}$, $\mathrm{PhD}^{5,6}$, Matti Jauhiainen, $\mathrm{PhD}^{7}$, Stine M. Ulven, $\mathrm{PhD}^{2}$, Martin P. Bogsrud, MD, $\mathrm{PhD}^{1,8}$, Petri T. Kovanen, $\mathrm{MD}, \mathrm{PhD}^{3}$, Bente Halvorsen, $\mathrm{PhD}^{9,10}$, Michael N. Oda, $\mathrm{PhD}^{11}$, Cecilie Wium, MD, $\mathrm{PhD}^{12}$, Kjetil Retterst $\varnothing \mathrm{l}, \mathrm{MD}, \mathrm{PhD}^{2,12}$, Katariina Öörni, $\mathrm{PhD}^{3,13 *}$ and Kirsten B. Holven, $\mathrm{PhD}^{1,2 *}$

*Shared last authorship

1 Norwegian National Advisory Unit on Familial Hypercholesterolemia, Department of Endocrinology, Morbid Obesity and Preventive Medicine, Oslo University Hospital, Forskningsveien 2B, 0373 Oslo, Norway

2 Department of Nutrition, Institute of Basic Medical Sciences, University of Oslo, Sognsvannsveien 9, 0372 Oslo, Norway

3 Atherosclerosis Research Laboratory, Wihuri Research Institute, Helsinki, Finland 4 Research Programs Unit, Faculty of Medicine, University of Helsinki, Finland 5 Pediatric Department, Oslo University Hospital Ullevaal, Oslo, Norway

6 Oslo Diabetes Research Centre, Oslo, Norway

7 Minerva Foundation Institute for Medical Research and National Institute for Health and Welfare, Biomedicum 2U, Helsinki, Finland

8 Unit for Cardiac and Cardiovascular Genetics, Oslo University Hospital, Norway 9 Research Institute of Internal Medicine, Oslo University Hospital Rikshospitalet, 0424 Oslo, 
medRxiv preprint doi: https://doi.org/10.1101/2020.11.11.20214247; this version posted November 13,2020 . The copyright holder for this preprint (which was not certified by peer review) is the author/funder, who has granted medRxiv a license to display the preprint in It is made available under a CC-BY-NC-ND 4.0 International license .

10 Faculty of Medicine, University of Oslo, 0424 Oslo, Norway

11 Seer BioLogics, Inc., Fairfield, CA, 94534, United States

12 The Lipid Clinic, Oslo University Hospital, Norway

13 Molecular and Integrative Biosciences Research Programme, Faculty of Biological and Environmental Sciences, University of Helsinki, Finland

Correspondence: Jacob J. Christensen, PhD; e-mail: j.j.christensen@medisin.uio.no

Disclaimers: None.

Short running head: Lipoprotein function

Word count: 4214 (from Introduction to Authorship)

Abbreviations: apoA-I, apolipoprotein A-I; apoB, apolipoprotein B; ASCVD, atherosclerotic cardiovascular disease; BMI, body mass index; BCAAs, branched-chain amino acids; CETP, cholesteryl ester transfer protein; DHA, docosahexaenoic acid; FA, fatty acids; FH, familial hypercholesterolemia; HAE, HDL-apoA-I exchange; HDL, high-density lipoprotein; LA, linoleic acid; LCAT, lecithin-cholesterol acyltransferase; LDL, low-density lipoprotein; LDL aggr (PP), LDL aggregation (per particle); LDL aggr (TL), LDL aggregation (total load); LDLR, LDL receptor; MUFA, monounsaturated fatty acids; n3, omega-3 fatty acids; n6, omega-6 fatty acids; PC, phosphatidylcholine; PLTP, phospholipid transfer protein; PON1, paraoxonase-1; PUFA, polyunsaturated fatty acids; RCT, reverse cholesterol transport; SFA, saturated fatty acids; SM, sphingomyelins; VLDL, very low-density lipoprotein 
medRxiv preprint doi: https://doi.org/10.1101/2020.11.11.20214247; this version posted November 13,2020 . The copyright holder for this preprint (which was not certified by peer review) is the author/funder, who has granted medRxiv a license to display the preprint in It is made available under a CC-BY-NC-ND 4.0 International license .

\section{Abstract}

2 Background: The functional status of lipoprotein particles contributes to atherogenesis. The

3 tendency of plasma LDL particles to aggregate and the ability of HDL particles to induce and

4 mediate reverse cholesterol transport associate with high and low risk for cardiovascular

5 disease in adult patients, respectively. However, it is unknown whether children with familial

6 hypercholesterolemia (FH) display lipoprotein function alterations.

7 Hypothesis: We hypothesized that FH children had disrupted lipoprotein function.

8 Methods: We analyzed LDL aggregation susceptibility and HDL-apoA-I exchange to apoA-I

9 ratio (HAE/apoA-I ratio), and activity of four proteins that regulate lipoprotein metabolism

10 (CETP, LCAT, PLTP and PON1) in plasma samples derived from children with FH $(n=47)$ and

11 from healthy children $(n=56)$. Potential biological mechanisms behind any variation in

12 lipoprotein functionalities were explored using an NMR-based metabolomics profiling

13 approach.

14 Results: LDL aggregation was higher and HAE/apoA-I ratio was lower in FH children than in 15 healthy children. LDL aggregation associated positively with LDL-C and negatively with

16 triglycerides, and HAE/apoA-I ratio associated negatively with LDL-C. Generally, the

17 metabolomic profile for LDL aggregation was a mirror image of that for HAE/apoA-I ratio.

18 Conclusions: FH children displayed increased atherogenicity of LDL and disrupted HDL

19 function. These newly observed functional alterations in LDL and HDL may increase the risk

20 for atherosclerotic cardiovascular disease in FH children. 
medRxiv preprint doi: https://doi.org/10.1101/2020.11.11.20214247; this version posted November $13,2020$. The copyright holder for this preprint (which was not certified by peer review) is the author/funder, who has granted medRxiv a license to display the preprint in It is made available under a CC-BY-NC-ND 4.0 International license

22 Keywords: Lipoproteins, familial hypercholesterolemia, LDL aggregation, HAE/apoA-I ratio,

23 reverse cholesterol transport, cholesterol, children, ASCVD, metabolomics, NMR 
medRxiv preprint doi: https://doi.org/10.1101/2020.11.11.20214247; this version posted November 13,2020 . The copyright holder for this preprint (which was not certified by peer review) is the author/funder, who has granted medRxiv a license to display the preprint in It is made available under a CC-BY-NC-ND 4.0 International license.

\section{Introduction}

Besides the plasma concentration, lipoprotein particle function is emerging as an important

factor in the progression of atherosclerotic cardiovascular disease (ASCVD) $(1,2)$. Low-

density lipoprotein (LDL) particles undergo significant modifications in vivo, particularly in the unique microenvironment in the arterial wall, via oxidizing agents, proteases, and lipases (2). Modified LDL particles are prone to aggregation, and the tendency for LDL particles to aggregate is one of several metrics of LDL function, predictive of ASCVD risk (3). Furthermore, the spectrum of high-density lipoprotein (HDL) particles and apolipoprotein A-I (apoA-I) have specific roles in reverse cholesterol transport (RCT), a process that conveys cholesterol and lipids from peripheral tissues to the liver. HDL function can be quantified by metrics of RCT, including cholesterol efflux capacity (CEC) or HDL-apoA-I exchange to apoA-I ratio (HAE/apoA-I ratio) (4), measures also predictive of ASCVD risk $(5,6)$.

Because dyslipidemia drives ASCVD, a major cause of disability and death worldwide (1), and because lipoprotein modification connects lipids and inflammation in atherosclerosis (2), biomarkers of lipoprotein function have the potential to identify ASCVD risk well in advance of acute pathological manifestation. However, it is unclear whether children display measurable alterations in lipoprotein function. We reasoned that children with familial hypercholesterolemia $(\mathrm{FH})$ would be a suitable group to examine this research question. Patients with FH show elevated plasma LDL cholesterol (LDL-C) since birth, and a variety of markers of atherosclerotic development are observable even in early childhood (7). We therefore hypothesized that FH children would have disrupted lipoprotein function. 
medRxiv preprint doi: https://doi.org/10.1101/2020.11.11.20214247; this version posted November $13,2020$. The copyright holder for this preprint (which was not certified by peer review) is the author/funder, who has granted medRxiv a license to display the preprint in It is made available under a CC-BY-NC-ND 4.0 International license .

47

48

49

50

51

52

53

54

55

56

57

58

59

60

61

62

63

64

65

66

67

68

\section{Subjects and methods}

The present study is a cross-sectional analysis of FH children and healthy children. We have reported research findings from the same populations previously $(8,9)$ (Figure S1, Table S1).

\section{Study design, setting and participants}

Briefly, we recruited $47 \mathrm{FH}$ children from the outpatient Lipid Clinic at Oslo University Hospital (OUH) in Oslo, Norway (9). All children had a definite FH diagnosis, verified by genetic or clinical diagnosis, the latter based on the Simon Broome criteria (10). Eighteen children (38\%) were currently on statins, and 20 (43\%) had LDL receptor (LDLR) negative mutations (Supplementary Material) $(9,11)$. Furthermore, we included 56 non-FH, healthy children that were part of the Stork children follow-up study at Department of Nutrition, University of Oslo (UoO) in Oslo, Norway $(8,12)$. Data collection occurred in the period September 2013 to October 2015.

All children, and their parents when the child was under 16 years, gave written informed consent to participate in the study. The Regional Committee for Research Ethics in South East Norway approved the study, and the study protocol was in accordance with the declaration of Helsinki.

Data measurements and variables

We obtained clinical and biochemical data as previously described $(8,12)$. Briefly, we assessed clinical variables at the time of visit, including weight, height, and statin use. We collected blood samples at time of visit, and consecutively analyzed standard biochemistry in heparin-plasma at the Department of Medical Biochemistry, OUH. Data collection for the two groups of children was conducted by different researchers but followed the same 
medRxiv preprint doi: https://doi.org/10.1101/2020.11.11.20214247; this version posted November 13,2020 . The copyright holder for this preprint (which was not certified by peer review) is the author/funder, who has granted medRxiv a license to display the preprint in It is made available under a CC-BY-NC-ND 4.0 International license.

69

standardized research protocol to reduce the impact of information bias. Apart from during the data collection phase, all laboratory analyses (described in the following) were performed with the analysts being blinded to FH status, statin use, sex, or any other characteristics.

\section{LDL aggregation assay}

We analyzed LDL aggregation as previously described, given in brief in Supplementary Material $(3,13)$. In accordance with previous reports, we herein analyzed LDL aggregation values for the two-hour timepoint. Because we normalized input to the aggregation assay to $0.2 \mathrm{mg}$ apoB-100/mL, effectively adjusting for $\mathrm{LDL}-\mathrm{C}$, this represents a per particle (PP) metric of LDL aggregation. The LDL aggregation (PP) represents the LDL aggregation variable reported in other studies $(3,13)$. We engineered an additional variable by multiplying LDL aggregation values by laboratory-measured LDL protein concentration. Because this second variable considers the totality of LDL exposure, that is, unadjusted for LDL-C, it represents a total load (TL) metric of LDL aggregation. Although we present both variables in figures, we consider the latter clinically most important and appropriate; hence, we mostly describe $L D L$ aggregation (TL) throughout the manuscript text.

HDL-apoA-I exchange (HAE) assay

We analyzed the HAE/apoA-I ratio as previously described, and summarized in Supplementary Material (4). HAE/apoA-I is a measure of HDLs ability to "exchange" apoA-I, normalized relative to apoA-I plasma level. ApoA-I exchange in the intima is required for HDL biogenesis so HAE/apoA-I therefore indirectly reflects HDL's ability to initiate RCT. In contrast, the cell-based CEC assay, which measures the potential of macrophages to deliver cholesterol to lipid-poor apoA-I, is considered the gold standard of HDL function assessment 
medRxiv preprint doi: https://doi.org/10.1101/2020.11.11.20214247; this version posted November 13,2020 . The copyright holder for this preprint (which was not certified by peer review) is the author/funder, who has granted medRxiv a license to display the preprint in It is made available under a CC-BY-NC-ND 4.0 International license .

92 (14). While well established, the CEC method has not been standardized and is subject to the

93 variability induced by cell culture methods. Despite this, the HAE/apoA-I ratio strongly

94 correlates with CEC, and $\mathrm{s}$ a result the HAE/apoA-I ratio is an effective and highly

95 reproducible surrogate biomarker of CEC (15).

96 Lipoprotein metabolism-regulating proteins

97 We analyzed the activity of four proteins that participate in the regulation of lipoprotein

98 metabolism: cholesteryl ester transfer protein (CETP), lecithin-cholesterol acyltransferase

99 (LCAT), phospholipid transfer protein (PLTP) and paraoxonase-1 (PON1). CETP activity

$100(\mathrm{nmol} / \mathrm{mL} / \mathrm{h})$ was analyzed as the transfer/exchange of radiolabeled $\left[{ }^{14} \mathrm{C}\right]$-cholesteryl oleate

101 between exogenously added human LDL and HDL2, as described (16). LCAT activity

$102(\mathrm{nmol} / \mathrm{ml} / \mathrm{h})$ was assessed by measuring cholesterol esterification activity using exogenous

$103\left[{ }^{3} \mathrm{H}\right]$-cholesterol-labelled HDL proteoliposome discs as the substrate (17). PLTP activity

$104(\mathrm{nmol} / \mathrm{ml} / \mathrm{h})$ was determined with a radiometric method as described (18). PON1 (umol/min)

105 activity was measured with a chromogenic method (19).

106 Quantitative NMR metabolomics

107 We measured a broad set of biomarkers involved in human metabolism-related health and

108 disease using a commercially available, high-throughput nuclear magnetic resonance (NMR)

109 spectroscopy platform (Nightingale Health, Finland) (20). The method is thoroughly

110 described in separate reports $(20,21)$. Briefly, the biomarkers covered particle concentration

111 and lipid content of 14 subclasses of lipoproteins, and plasma fatty acids, amino acids,

112 glucose metabolites, ketone bodies and other biomarkers, including certain protein

113 biomarkers. In contrast to our previous work which was based on the original 2016

114 algorithm (9), the data values for the present analysis were estimated using the 2020 
medRxiv preprint doi: https://doi.org/10.1101/2020.11.11.20214247; this version posted November 13,2020 . The copyright holder for this preprint (which was not certified by peer review) is the author/funder, who has granted medRxiv a license to display the preprint in It is made available under a CC-BY-NC-ND 4.0 International license.

115

116

117

118

120

121

122

123

124

126

127

128

130

131

132

133 were zero for two FH children. We changed all these to missing. Finally, we imputed missing

137

algorithm (Nightingale Health, Finland). Note also that previous metabolomics analyses regarding LDL aggregation was based on LC-MS, not NMR (3).

Data analyses

We performed all data analyses in R version 4.0.0 (22) using RStudio (Boston, MA, USA, www.rstudio.com) and the tidyverse framework, including data cleaning, data manipulation, data modeling, and data visualization (23). Thorough exploratory data analysis guided all data analysis decision-making described below. We refer to $\mathrm{R}$ packages and functions where appropriate using the following notation: package: : function.

\section{Feature engineering}

We calculated body mass index (BMI) z score based on World Health Organization (WHO)

Growth References (addWGSR: : zscorer) (24). Furthermore, we addressed missing data with the following strategies. First, for CRP, estradiol, and testosterone, 80, 55 and 44 participants had values below or exactly at detection limits of $0.6 \mathrm{mg} / \mathrm{L}, 0.04 \mathrm{nmol} / \mathrm{L}$ and 0.4 $\mathrm{nmol} / \mathrm{L}$, respectively. We imputed these entries manually by generating a random uniform between zero and specific detection limit (stats: : runif). Additionally, a single participant had missing entries for estradiol and testosterone. Second, for HAE/apoA-I ratio, we changed a single entry to missing because it was unlikely high (>58), totaling 13 missing entries for FH children for this variable. Additionally, the concentration and lipid content of the largest lipoprotein particles was zero for many subjects, likely because of values being below the detection limit. For XXL-VLDL particles and lipids, 27 entries were zero (covering both FH children and healthy children); similarly, for XL-VLDL particles and lipids, entries entries with the k-nearest neighbors (kNN) algorithm within the tidymodels framework 
medRxiv preprint doi: https://doi.org/10.1101/2020.11.11.20214247; this version posted November $13,2020$. The copyright holder for this preprint (which was not certified by peer review) is the author/funder, who has granted medRxiv a license to display the preprint in It is made available under a CC-BY-NC-ND 4.0 International license.

(recipes: :recipe and recipes: :step_knnimpute to impute, and recipes: : prep and recipes: :juice to collect the imputed dataset).

140 Furthermore, also prior to modeling, we $\log _{\mathrm{e}}$ transformed (ba se : : log) all right skewed

141 continuous exposures and outcomes to normal distributions. Right skewness was objectively

142 defined as skewness $>1$ (e1071: : skewness). For the lipoprotein function metrics and

143 lipoprotein metabolism-regulating proteins, this applied to the LDL aggregation variables (PP 144 and TL) and PON1 only (see Table S2 for the full overview); following transformations, these

145 biomarkers displayed normal distributions except PON1, which showed a bivariate

146 distribution, likely related to genetic variation (25). Next, we normalized all continuous

147 variables to standard normal distributions, that is, with mean equal to zero and standard

148 deviation equal to one (base: :scale), to aid comparison of magnitudes and to aid

149 visualization of the results. Consequently, the $\beta$ regression coefficients for continuous

150 variables can be interpreted as per 1 standard deviation increase.

151 Linear models

152 We examined lipoprotein function metrics and lipoprotein metabolism-regulating proteins in

153 FH children and healthy children; however, our statistical analyses were divided into two

154 parts, described below. We used ordinary linear regression models (stats : : $1 \mathrm{~m}$ ) to explore

155 crude models and models adjusted for one or more of the following covariates: age, sex, BMI

$156 \mathrm{z}$ score, triglycerides, statin use and mutation type. All associations we present herein are

157 multivariable linear regression models adjusted for age, sex, and BMI z score; other

158 univariate or multivariate models with different adjustment levels were relatively similar.

159 We first compared lipoprotein function metrics and lipoprotein metabolism-regulating

160 proteins (seven outcomes) in FH children with healthy children (one exposure), for example 
medRxiv preprint doi: https://doi.org/10.1101/2020.11.11.20214247; this version posted November 13,2020 . The copyright holder for this preprint (which was not certified by peer review) is the author/funder, who has granted medRxiv a license to display the preprint in It is made available under a CC-BY-NC-ND 4.0 International license .

161 like so: $L D L$ aggregation (TL) FH status + covariates. In this set of models, we also examined

162 FH subgroups: statin users, non-statin users, LDLR negative mutations, and other mutations.

163 Secondly, we performed a more comprehensive analysis: we examined the variation in LDL

164 aggregation (PP), LDL aggregation (TL) and HAE/apoA-I ratio (three outcomes) across all

165 clinical variables and biomarkers covered by the NMR metabolomics platform (98-99

166 exposures), for example like so: $L D L$ aggregation $(T L) \sim L-L D L-P+$ covariates. In the second

167 part, we performed the analyses for all children combined (306 models), and separately for

168 FH children (312 models) and healthy children (306 models), yielding a total of 924 models.

169 Significance and power

170 For the first analysis part, we set alpha level to 0.05 . In the second part, we did not consider

171 significance in the usual way. Instead, we interpreted the direction and strength of the $\beta$

172 regression estimates, the uncertainty around those estimates, and the relationship between

173 variables. Still, we reported significance by standard cutoffs in the figures: $P<0.001, P<$

$1740.01, P<0.05$ and $P \geq 0.05$, to aid translation of the results.

175 We did not perform a priori power calculations for the present study. However, to give an

176 indication of the power of our analyses, we performed simple post hoc power calculations

177 for the general linear model (pwr: :pwr.f2. test), yielding the following result. Given six

178 degrees of freedom, for an association quantified by an $\mathrm{R}^{2}$ (explained variance) of 0.13

179 (which corresponds to the median $\mathrm{R}^{2}$ among our associations), to have $80 \%$ power, we

180 would have needed a total sample size of approximately 98,135 and 184 subjects, for $P$

181 value thresholds of $0.05,0.01$ and 0.001 , respectively. 
medRxiv preprint doi: https://doi.org/10.1101/2020.11.11.20214247; this version posted November $13,2020$. The copyright holder for this preprint (which was not certified by peer review) is the author/funder, who has granted medRxiv a license to display the preprint in It is made available under a CC-BY-NC-ND 4.0 International license .

\section{Miscellaneous}

183 For the descriptive Tables S1 and S3, we calculated relevant summary statistics, including

184 mean and standard deviation (for normally distributed, continuous variables), median and

185 interquartile range (for skewed, continuous variables), and frequency and percentage (for

186 categorical variables). We also compared groups using Independent Samples T tests or Chi-

187 squared tests, as appropriate. 
medRxiv preprint doi: https://doi.org/10.1101/2020.11.11.20214247; this version posted November $13,2020$. The copyright holder for this preprint (which was not certified by peer review) is the author/funder, who has granted medRxiv a license to display the preprint in It is made available under a CC-BY-NC-ND 4.0 International license.

189

190

191

192

193

194

195

196

197

198

199

200

201

202

203

204

205

206

207

208

209

Lipoprotein function metrics associated with various lipid subclasses and metabolites,

\section{Results}

FH children had alterations in lipoprotein function metrics, which associated with clinical

parameters

We measured LDL aggregation, HAE/apoA-I ratio, and various plasma proteins that are important in vivo regulators of lipoprotein metabolism. Interestingly, FH children displayed higher LDL aggregation (PP), which was further enhanced when the total load of aggregating LDL (TL) was considered, and lower HAE/apoA-I ratio (Figure 1, Table S3). While adjusting for statin use and mutation type did not influence these associations (data not shown), nonstatin users and FH children with LDLR negative mutations generally displayed a more pronounced effect (Figure S2 and S3).

LDL aggregation (TL) and HAE/apoA-I ratio associated with several clinical parameters (Figure S3 and S4). Specifically, LDL aggregation (TL) associated positively with LDL-C and sex hormones, and negatively with triglycerides. HAE/apoA-I ratio associated negatively with LDL-C and sex hormones, in addition to age (Figure S3 and S4). Interestingly, in general, the associations for LDL aggregation (TL) and HAE/apoA-I ratio went in the opposite directions, except for triglycerides. Of note, while the associations for triglycerides were robust in subgroup analyses, the associations for LDL-C were not (Figure S4), likely because of the limited range in LDL-C (Figure S5).

The lipoprotein metabolism-regulating biomarkers displayed no clear differences across groups (Figure 1), although LCAT activity inversely associated with BMI and triglycerides (Figure S3). 
medRxiv preprint doi: https://doi.org/10.1101/2020.11.11.20214247; this version posted November $13,2020$. The copyright holder for this preprint (which was not certified by peer review) is the author/funder, who has granted medRxiv a license to display the preprint in It is made available under a CC-BY-NC-ND 4.0 International license .

212 Next, to explore further why LDL aggregation (PP and TL) and HAE/apoA-I ratio differed in FH

213 children and healthy children, we investigated the association of the lipoprotein function

214 metrics with several lipoprotein subclasses and metabolites covering key facets of human

215 metabolism.

216 LDL aggregation (TL) associated positively with LDL lipoprotein subclasses, apoB, VLDL

217 remnants (XS-VLDL and IDL) and LDL particle diameter, and inversely with major VLDL

218 particles and the smallest HDL particles (Figure 2, Table S2). Like for the clinical parameters

219 (Figure S3), LDL aggregation (TL) and HAE/apoA-I ratio patterns were largely mirror images

220 of each other. Furthermore, cholesterol fractions in LDL and VLDL (total, esterified or free)

221 associated positively with LDL aggregation (TL), and so did phospholipids in LDL, plasma total

222 sphingomyelins (SM), and the SM/phosphatidylcholine (PC) ratio (Figure 3, Table S2). The

223 proportion of triglycerides to total lipids (LDL-TG \%) and the ratio of CE to FC in LDL particles

224 (LDL-CE/FC) negatively associated with LDL aggregation (TL). In contrast, for HAE/apoA-I

225 ratio, most of the associations described above were in the opposite direction. Additionally,

226 triglycerides in VLDL or HDL and phospholipids in HDL associated negatively with LDL

227 aggregation (TL). Even more detailed subclass analyses showed the same trends (data not

228 shown).

229 PUFA, omega-6 and linoleic acid (LA) levels, as well as degree of unsaturation, all associated

230 positively with LDL aggregation (TL) and negatively with HAE/apoA-I ratio (Figure 4, Table

231 S2). Additionally, relative content of MUFA and SFA levels associated inversely with LDL

232 aggregation (TL). Omega-3 markers associated neither with LDL aggregation (TL) nor with

233 HAE/apoA-I ratio. Moreover, LDL aggregation (TL) associated inversely with levels of

234 branched-chain amino acids (BCAAs), and positively with levels of ketone bodies (Figure 5, 
medRxiv preprint doi: https://doi.org/10.1101/2020.11.11.20214247; this version posted November $13,2020$. The copyright holder for this preprint (which was not certified by peer review) is the author/funder, who has granted medRxiv a license to display the preprint in It is made available under a CC-BY-NC-ND 4.0 International license .

235 Table S2). Although HAE/apoA-I ratio again displayed associations in the opposite direction,

236 these were less pronounced.

237 Overall, biomarker associations were opposite for LDL aggregation (TL) and HAE/apoA-I ratio

238 With few exceptions, the associations between the lipoprotein function metrics and the

239 lipoprotein subclasses and metabolites headed in completely opposite directions for LDL

240 aggregation (TL) and HAE/apoA-I ratio (Figure 6, Table S2). 
medRxiv preprint doi: https://doi.org/10.1101/2020.11.11.20214247; this version posted November $13,2020$. The copyright holder for this preprint (which was not certified by peer review) is the author/funder, who has granted medRxiv a license to display the preprint in It is made available under a CC-BY-NC-ND 4.0 International license.

\section{Discussion}

243 In the present study, we demonstrated that FH children displayed disrupted lipoprotein

244 function compared with healthy children. Overall, the FH children were characterized by

245 enhanced LDL aggregation (both PP and TL) and attenuated HAE/apoA-I ratio, strongly

246 suggesting the presence of LDL particles with an increased atherogenicity and an impaired

247 function of HDL particles in the first step of RCT, respectively. Our results indicate that

248 variation in LDLR function, plasma LDL-C and cumulative cholesterol burden may jointly be

249 the overarching drivers and common denominators biologically linking these metrics.

250 FH children had LDL particles that were particularly prone to aggregation, as reflected by

251 high LDL aggregation (PP) in this group. Also considering the LDL protein concentration (LDL

252 aggregation [TL]), the difference between FH children and healthy children was even more

253 pronounced. These effects could contribute to the high risk of ASCVD in this population.

254 Aggregation of LDL particles typically occurs following their retention in the arterial

255 subendothelial intimal layer $(2,26-28)$, but our present results suggest that lipoproteins in

256 FH subjects could be primed for aggregation already while circulating in the blood,

257 potentially due to their increased residence time in plasma caused by the underlying LDLR

258 defect. In line with this, we previously showed that FH children have higher circulating levels

259 of oxidized LDL (29) and display a shift in blood monocytes towards a more pro-

260 inflammatory phenotype (12). We also observed previously that peripheral blood

261 mononuclear cells (PBMCs) in FH children are characterized by a pro-inflammatory

262 phenotype, which can be partially normalized upon initiation of statin treatment (30). Along

263 with the isolated hypercholesterolemia, these alterations in FH subjects could help explain

264 their elevated risk of ASCVD (31-33). Indeed, in the Finnish Corogene Study, baseline LDL 
medRxiv preprint doi: https://doi.org/10.1101/2020.11.11.20214247; this version posted November 13,2020 . The copyright holder for this preprint (which was not certified by peer review) is the author/funder, who has granted medRxiv a license to display the preprint in It is made available under a CC-BY-NC-ND 4.0 International license .

265

266

267

268

269

270

271

272

273

274

275

276

277

278

279

aggregation (PP) was higher in adult ASCVD patients who died during a 2.5-year follow-up

period, compared to those with stable coronary artery disease (3). In comparison, both of

these patient groups had higher LDL aggregation (PP) than healthy subjects in the Health 2000 Study (3).

FH children had lower HAE/apoA-I ratio compared with healthy children, which suggests that hypercholesterolemia impairs not only LDL function, but also one of the major HDLassociated atheroprotective functions, namely, cholesterol efflux from macrophages to HDL (34). These results support our previous data $(12,35)$. Importantly, in adult non-FH subjects CEC associated with atherosclerosis and predicted future ASCVD events independent of plasma HDL-C concentration $(5,6,36)$. In those analyses, the researchers adjusted for several covariates including LDL-C and concluded that the association with ASCVD was independent of classical risk factors. The present results suggest that prolonged exposure to high LDL-C in otherwise healthy children has an adverse effect on HDL function, HDL metabolism, and RCT. One mechanism could be related to oxidized LDL $(34,37)$. Work in experimental animals interestingly suggests that lack of functional hepatic LDLRs attenuate RCT via concerted action of the HDL-LDL-axis (38). Regardless of the mechanism, findings in adolescent FH subjects support that HDL function is altered early in life (39). The risk factor-related detrimental effect on RCT is likely not isolated to high LDL-C, though, as we previously observed similar alterations upon prolonged exposure to hyperglycemia in children with diabetes mellitus type I (4).

Clinical and biomarker associations for LDL aggregation (TL) and HAE/apoA-I ratio were largely mirror images of each other, suggesting that these features correlate. In our study populations, this was likely mediated by the variation in the concentration of circulating LDL 
medRxiv preprint doi: https://doi.org/10.1101/2020.11.11.20214247; this version posted November $13,2020$. The copyright holder for this preprint (which was not certified by peer review) is the author/funder, who has granted medRxiv a license to display the preprint in It is made available under a CC-BY-NC-ND 4.0 International license.

288

289

290

291

292

293

294

295

296

297

298

299

300

301

302

303

304

305

306

307

308

particles and associated downstream effectors such as oxidized LDL. Notably, for LDL

aggregation ( $T L)$, the strength and direction of associations and interrelations across all variables were practically identical to those seen for isolated hypercholesterolemia (9); for HAE/apoA-I ratio, associations were in the opposite direction. This included LDL lipoprotein particle subclasses, apoB, LDL diameter, cholesterol fractions in LDL and VLDL (total, esterified, free), phospholipids in LDL, SMs, PUFA, omega-6, and LA. Furthermore, although both LDL aggregation (TL) and HAE/apoA-I ratio associated with LDL-C, we observed an unexpected relationship with FH status: the results were not robust in analyses of $\mathrm{FH}$ children and healthy children separately (Figures 2-5 and S4). This Simpson's paradox-like behavior could, however, be explained by two factors: that subgroup analyses in this case would equate to adjusting for the mediator in the causal pathway (that is, LDL-C), and the limited range in LDL-C observed within each group (Figure S5). In contrast, the effects of the mutation type and statin use on the studied metrics (LDL aggregation [TL] and HAE/apoA-I ratio) were in the expected directions: when compared with healthy children, LDLR negative mutations and lack of statin use were more detrimental, and other LDLR mutations and statin use were less detrimental. Taken together, it seems likely that variation in LDLR function, plasma LDL-C and cumulative cholesterol burden may jointly be the overarching drivers and common denominators biologically linking these metrics. Consequently, these findings could be extrapolated to variation in cholesterol burden in non-FH populations.

Paradoxically, LDL aggregation associated inversely with triglycerides, suggesting that higher triglyceride levels within the normal triglyceride range were protective. The Spearman's correlation coefficients for LDL aggregation and triglycerides were -0.39 (PP) and -0.25 (TL), respectively. This finding was consistent in subgroup analyses, and is also corroborated by similar results from other studies: in the Health 2000 Study and the Corogene Study, the 
medRxiv preprint doi: https://doi.org/10.1101/2020.11.11.20214247; this version posted November $13,2020$. The copyright holder for this preprint (which was not certified by peer review) is the author/funder, who has granted medRxiv a license to display the preprint in It is made available under a CC-BY-NC-ND 4.0 International license.

correlations between LDL aggregation (PP) and triglycerides were -0.28 and -0.38 ,

327 The present work has certain limitations that warrant mention. First, this is an observational,

328 cross-sectional analysis, thus, we can neither infer causality nor rule out residual

329 confounding factors. However, because FH is a well-characterized human genetic disorder, 330 we feel confident that the LDLR mutations caused an increase in LDL-C prior to all other 331 alterations (42). Also, the effect of confounding factors is likely lower in children than in 332 adults, regardless of FH status. Second, the number of study participants was low, which 333 increases the probability of false positive and negative findings. To meet this issue, we did not emphasize significance, but rather focused on the direction and strength of associations, 
medRxiv preprint doi: https://doi.org/10.1101/2020.11.11.20214247; this version posted November $13,2020$. The copyright holder for this preprint (which was not certified by peer review) is the author/funder, who has granted medRxiv a license to display the preprint in It is made available under a CC-BY-NC-ND 4.0 International license.

children were not collected for a single study; rather, they were part of separate

337 recruitments, which likely introduced bias in both data collection and standard clinical and

338 biochemical data measurements. However, we performed data collection during a single

339 period and adhered to strict study protocols to attenuate the potential bias. Also, the

340 lipoprotein function metrics, lipoprotein metabolism-regulating proteins and NMR metrics

341 were analyzed collectively by highly standardized protocols. Importantly, in this phase the

342 analysts were blinded to the subject characteristics. Finally, we did not perform LC-MS in-

343 depth proteomic and lipidomic analyses of the LDL particles, which could have shed light

344 both on the triglyceride paradox and whether the specific characteristics of the particles

345 represented a shared mechanistic link between LDL aggregation and HDL efflux.

346 To the best of our knowledge, this is the first study that comprehensively examines LDL and

347 HDL lipoprotein function metrics in FH children, thus expanding our knowledge and

348 understanding about these relevant biomarkers of ASCVD risk in severe early-life

349 hypercholesterolemia. Although FH is a genetic disorder, the atherosclerotic process is

350 similar in all humans, which to a large degree enables translation of our findings to the

351 general population.

352 In conclusion, FH children were characterized by disrupted lipoprotein function compared

353 with healthy children, which was related to differences in plasma lipids and lipoproteins.

354 Higher LDL-C associated with both higher LDL aggregation (TL) and lower HAE/apoA-I ratio,

355 suggesting that LDLR function and plasma LDL-C may be the overarching drivers and

356 common denominators linking these metrics in a biologically relevant context. For more

357 strict causal verification, these molecular aspects need further detailed mechanism-based

358 investigations. 
medRxiv preprint doi: https://doi.org/10.1101/2020.11.11.20214247; this version posted November 13,2020 . The copyright holder for this preprint (which was not certified by peer review) is the author/funder, who has granted medRxiv a license to display the preprint in It is made available under a CC-BY-NC-ND 4.0 International license .

359

360

361

362

363

364

365

366

367

368

369

370

371

372

373

374

375

376

377

378 Norwegian Directorate of Health, Sanofi, Takeda, Chiesi, Bayer, MSD, and research grants

379 from Oslo Economics and Mills outside the submitted work. Dr. Heier has received a

\section{Acknowledgements}

We would like to thank all children and families that kindly chose to participate in our research studies. We would also like to thank technician Maija Atuegwu for helpful assistance with laboratory analyses.

\section{Sources of support}

This work was funded by the University of Oslo (Oslo, Norway), the National Advisory Unit on FH at OUH (Oslo, Norway), the Throne-Holst Foundation for Nutrition Research (Oslo, Norway), the South-Eastern Regional Health Authority (Oslo, Norway), the Academy of Finland (\#315568 and \#332564 to KÖ), the Jane and Aatos Erkko Foundation (to MJ), the Finnish Foundation for Cardiovascular Research (to MJ and KÖ), the Aarne Koskelo Foundation (to KÖ), and the Novo Nordisk Foundation (to KÖ). Wihuri Research Institute is maintained by the Jenny and Antti Wihuri Foundation.

\section{Conflicts of interest}

Dr. Christensen has received research grants and/or personal fees from Mills DA, unrelated to the content of this manuscript. Drs. Ruuth, Kovanen and Öörni have applied for a patent on the LDL aggregation method; otherwise they have no other relevant financial relationships to disclose. Dr. Ulven has received research grants from Tine DA, Mills DA, and Olympic Seafood, none of which are related to the content of this manuscript. Dr. Retterstøl reports personal fees from Amgen, Mills DA, The Norwegian Medical Association, The research grant from the Norwegian Diabetes Association for analyses included in this manuscript. Dr. Holven has received research grants and/or personal fees from Tine DA, 
medRxiv preprint doi: https://doi.org/10.1101/2020.11.11.20214247; this version posted November 13, 2020. The copyright holder for this preprint (which was not certified by peer review) is the author/funder, who has granted medRxiv a license to display the preprint in It is made available under a CC-BY-NC-ND 4.0 International license .

382 Mills DA, Olympic Seafood, Amgen, Sanofi, and Pronova, none of which are related to the

383 content of this manuscript. The other authors have no relevant financial relationships to

384 disclose.

\section{Authorship}

386 Conception and design: JJC, IN, SMU, KÖ, KBH; data collection: JJC, IN, MR, MH, MJ, MPB,

$387 \mathrm{MO}, \mathrm{CW}, \mathrm{KR}$; data analysis: JJC, IN, MR, MH, MJ, PK, MO, KÖ, KBH; data interpretation: all 388 authors, wrote paper and responsibility for final content: JJC, KÖ, KBH; all authors read, 389 critically revised and approved the final manuscript. 
medRxiv preprint doi: https://doi.org/10.1101/2020.11.11.20214247; this version posted November 13,2020 . The copyright holder for this preprint (which was not certified by peer review) is the author/funder, who has granted medRxiv a license to display the preprint in It is made available under a CC-BY-NC-ND 4.0 International license .

\section{References}

1. Ference BA, Ginsberg HN, Graham I, Ray KK, Packard CJ, Bruckert E, Hegele RA, Krauss RM, Raal FJ, Schunkert H, et al. Low-density lipoproteins cause atherosclerotic cardiovascular disease. 1. Evidence from genetic, epidemiologic, and clinical studies. A consensus statement from the European Atherosclerosis Society Consensus Panel. Eur Heart J. 2017;38:2459-72.

2. Borén J, Chapman MJ, Krauss RM, Packard CJ, Bentzon JF, Binder CJ, Daemen MJ, Demer LL, Hegele RA, Nicholls SJ, et al. Low-density lipoproteins cause atherosclerotic cardiovascular disease: pathophysiological, genetic, and therapeutic insights: a consensus statement from the European Atherosclerosis Society Consensus Panel. Eur Heart J [Internet]. [cited 2020 Feb 13]; Available from:

https://academic.oup.com/eurheartj/advancearticle/doi/10.1093/eurheartj/ehz962/5735221

3. Ruuth M, Nguyen SD, Vihervaara T, Hilvo M, Laajala TD, Kondadi PK, Gisterå A, Lähteenmäki H, Kittilä T, Huusko J, et al. Susceptibility of low-density lipoprotein particles to aggregate depends on particle lipidome, is modifiable, and associates with future cardiovascular deaths. Eur Heart J. 2018;39:2562-73.

4. Heier M, Borja MS, Brunborg C, Seljeflot I, Margeirsdottir HD, Hanssen KF, DahlJørgensen K, Oda MN. Reduced HDL function in children and young adults with type 1 diabetes. Cardiovasc Diabetol [Internet]. 2017 [cited 2020 Apr 30];16:85. Available from: http://cardiab.biomedcentral.com/articles/10.1186/s12933-017-0570-2 
medRxiv preprint doi: https://doi.org/10.1101/2020.11.11.20214247; this version posted November 13,2020 . The copyright holder for this preprint (which was not certified by peer review) is the author/funder, who has granted medRxiv a license to display the preprint in It is made available under a CC-BY-NC-ND 4.0 International license .

5. Khera AV, Cuchel M, de la Llera-Moya M, Rodrigues A, Burke MF, Jafri K, French BC, Phillips JA, Mucksavage ML, Wilensky RL, et al. Cholesterol efflux capacity, high-density lipoprotein function, and atherosclerosis. N Engl J Med. 2011;364:127-35.

6. Rohatgi A, Khera A, Berry JD, Givens EG, Ayers CR, Wedin KE, Neeland IJ, Yuhanna IS, Rader DR, de Lemos JA, et al. HDL cholesterol efflux capacity and incident cardiovascular events. N Engl J Med. 2014;371:2383-93.

7. Narverud I, Retterst $\varnothing I$ K, Iversen PO, Halvorsen B, Ueland T, Ulven SM, Ose L, Aukrust P, Veierød MB, Holven KB. Markers of atherosclerotic development in children with familial hypercholesterolemia: a literature review. Atherosclerosis. 2014;235:299-309.

8. Christensen JJ, Retterst $\varnothing \mid$ K, Godang K, Roland MCP, Qvigstad E, Bollerslev J, Ueland T, Henriksen T, Holven KB. LDL cholesterol in early pregnancy and offspring cardiovascular disease risk factors. J Clin Lipidol. 2016;10:1369-1378.e7.

9. Christensen JJ, Ulven SM, Retterst $\varnothing \mid$ K, Narverud I, Bogsrud MP, Henriksen T, Bollerslev J, Halvorsen B, Aukrust P, Holven KB. Comprehensive Lipid and Metabolite Profiling of Children with and without Familial Hypercholesterolemia: A Cross-Sectional Study. Atherosclerosis. 2017;266:48-57.

10. Risk of fatal coronary heart disease in familial hypercholesterolaemia. Scientific Steering Committee on behalf of the Simon Broome Register Group. BMJ. 1991;303:893-6.

11. Narverud I, van Lennep JR, Christensen JJ, Versmissen J, Gran JM, Iversen PO, Aukrust P, Halvorsen B, Ueland T, Ulven SM, et al. Maternal Inheritance Does Not Predict 
medRxiv preprint doi: https://doi.org/10.1101/2020.11.11.20214247; this version posted November 13,2020 . The copyright holder for this preprint (which was not certified by peer review) is the author/funder, who has granted medRxiv a license to display the preprint in It is made available under a CC-BY-NC-ND 4.0 International license .

Cholesterol Levels in Children with Familial Hypercholesterolemia. Atherosclerosis.

2015;243:155-60.

12. Christensen JJ, Osnes LT, Halvorsen B, Retterst $\varnothing$ I K, Bogsrud MP, Wium C, Svilaas A, Narverud I, Ulven SM, Aukrust P, et al. Altered Leukocyte Distribution under Hypercholesterolemia: A Cross-Sectional Study in Children with Familial Hypercholesterolemia. Atherosclerosis. 2017;256:67-74.

13. Ruuth M, Janssen LGM, Äikäs L, Tigistu-Sahle F, Nahon KJ, Ritvos O, Ruhanen H, Käkelä R, Boon MR, Öörni K, et al. LDL aggregation susceptibility is higher in healthy South Asian compared with white Caucasian men. J Clin Lipidol. 2019;13:910-919.e2.

14. de la Llera-Moya M, Drazul-Schrader D, Asztalos BF, Cuchel M, Rader DJ, Rothblat GH. The ability to promote efflux via ABCA1 determines the capacity of serum specimens with similar high-density lipoprotein cholesterol to remove cholesterol from macrophages. Arterioscler Thromb Vasc Biol. 2010;30:796-801.

15. Borja MS, Ng KF, Irwin A, Hong J, Wu X, Isquith D, Zhao X-Q, Prazen B, Gildengorin V, Oda MN, et al. HDL-apolipoprotein A-I exchange is independently associated with cholesterol efflux capacity. J Lipid Res. 2015;56:2002-9.

16. Groener JE, Pelton RW, Kostner GM. Improved estimation of cholesteryl ester transfer/exchange activity in serum or plasma. Clin Chem. 1986;32:283-6.

17. Jauhiainen M, Dolphin PJ. Human plasma lecithin-cholesterol acyltransferase. An elucidation of the catalytic mechanism. J Biol Chem. 1986;261:7032-43. 
medRxiv preprint doi: https://doi.org/10.1101/2020.11.11.20214247; this version posted November 13,2020 . The copyright holder for this preprint (which was not certified by peer review) is the author/funder, who has granted medRxiv a license to display the preprint in It is made available under a CC-BY-NC-ND 4.0 International license .

18. Jauhiainen $\mathrm{M}$, Ehnholm C. Determination of human plasma phospholipid transfer protein mass and activity. Methods. 2005;36:97-101.

19. Kleemola P, Freese R, Jauhiainen M, Pahlman R, Alfthan G, Mutanen M. Dietary determinants of serum paraoxonase activity in healthy humans. Atherosclerosis. 2002;160:425-32.

20. Soininen $P$, Kangas AJ, Würtz $P$, Suna $T$, Ala-Korpela M. Quantitative serum nuclear magnetic resonance metabolomics in cardiovascular epidemiology and genetics. Circ Cardiovasc Genet. 2015;8:192-206.

21. Soininen $P$, Kangas AJ, Würtz $P$, Tukiainen $T$, Tynkkynen $T$, Laatikainen $R$, Järvelin $M-R$, Kähönen M, Lehtimäki T, Viikari J, et al. High-throughput serum NMR metabonomics for cost-effective holistic studies on systemic metabolism. The Analyst. 2009;134:1781-5.

22. R Core Team. R: A Language and Environment for Statistical Computing. Vienna, Austria; 2019.

23. Wickham H, Averick M, Bryan J, Chang W, McGowan L, François R, Grolemund G, Hayes A, Henry L, Hester J, et al. Welcome to the Tidyverse. J Open Source Softw [Internet]. 2019 [cited 2020 Jun 2];4:1686. Available from: https://joss.theoj.org/papers/10.21105/joss.01686

24. de Onis M. Development of a WHO growth reference for school-aged children and adolescents. Bull World Health Organ [Internet]. 2007 [cited 2020 Jul 8];85:660-7. Available from: http://www.who.int/bulletin/volumes/85/9/07-043497.pdf 
medRxiv preprint doi: https://doi.org/10.1101/2020.11.11.20214247; this version posted November 13,2020 . The copyright holder for this preprint (which was not certified by peer review) is the author/funder, who has granted medRxiv a license to display the preprint in It is made available under a CC-BY-NC-ND 4.0 International license .

25. Mackness B, Durrington PN, Mackness MI. Human Serum Paraoxonase. Gen Pharmacol Vasc Syst [Internet]. 1998 [cited 2020 Apr 13];31:329-36. Available from: http://www.sciencedirect.com/science/article/pii/S0306362398000287

26. Öörni K, Pentikäinen MO, Ala-Korpela M, Kovanen PT. Aggregation, fusion, and vesicle formation of modified low density lipoprotein particles: molecular mechanisms and effects on matrix interactions. J Lipid Res [Internet]. American Society for Biochemistry and Molecular Biology; 2000 [cited 2020 May 1];41:1703-14. Available from: http://www.jlr.org/content/41/11/1703

27. Öörni K, Hakala JK, Annila A, Ala-Korpela M, Kovanen PT. Sphingomyelinase Induces Aggregation and Fusion, but Phospholipase A2 Only Aggregation, of Low Density Lipoprotein (LDL) Particles TWO DISTINCT MECHANISMS LEADING TO INCREASED BINDING STRENGTH OF LDL TO HUMAN AORTIC PROTEOGLYCANS. J Biol Chem [Internet]. American Society for Biochemistry and Molecular Biology; 1998 [cited 2020 May 1];273:29127-34. Available from: http://www.jbc.org/content/273/44/29127

28. Borén J, Williams KJ. The central role of arterial retention of cholesterol-rich apolipoprotein-B-containing lipoproteins in the pathogenesis of atherosclerosis: a triumph of simplicity. Curr Opin Lipidol. 2016;27:473-83.

29. Narverud I, Halvorsen B, Nenseter MS, RetterstøI K, Yndestad A, Dahl TB, Ulven SM, Olstad OK, Ose L, Holven KB, et al. Oxidized LDL level is related to gene expression of tumour necrosis factor super family members in children and young adults with familial hypercholesterolaemia. J Intern Med [Internet]. 2013 [cited 2019 Dec 19];273:69-78. Available from: http://doi.wiley.com/10.1111/j.1365-2796.2012.02584.x 
medRxiv preprint doi: https://doi.org/10.1101/2020.11.11.20214247; this version posted November 13,2020 . The copyright holder for this preprint (which was not certified by peer review) is the author/funder, who has granted medRxiv a license to display the preprint in It is made available under a CC-BY-NC-ND 4.0 International license .

30. Narverud I, Christensen JJ, Bakke SS, Ulven SM, Rundblad A, Aukrust P, Espevik T, Bogsrud MP, Retterst $\varnothing \mid K$, Ueland T, et al. Profiling of immune-related gene expression in children with familial hypercholesterolaemia. J Intern Med [Internet]. 2019 [cited 2019 Dec 19];joim.13001. Available from: https://onlinelibrary.wiley.com/doi/abs/10.1111/joim.13001

31. Krogh HW, Mundal L, Holven KB, Retterstøl K. Patients with familial hypercholesterolaemia are characterized by presence of cardiovascular disease at the time of death. Eur Heart J. 2016;37:1398-405.

32. Hu Pengwei, Dharmayat Kanika I., Stevens Christophe A.T., Sharabiani Mansour T.A., Jones Rebecca S., Watts Gerald F., Genest Jacques, Ray Kausik K., Vallejo-Vaz Antonio J. Prevalence of Familial Hypercholesterolemia Among the General Population and Patients With Atherosclerotic Cardiovascular Disease. Circulation [Internet]. American Heart Association; 2020 [cited 2020 Jun 2];141:1742-59. Available from: https://www.ahajournals.org/doi/full/10.1161/CIRCULATIONAHA.119.044795

33. Beheshti SO, Madsen CM, Varbo A, Nordestgaard BG. Worldwide Prevalence of Familial Hypercholesterolemia: Meta-Analyses of 11 Million Subjects. J Am Coll Cardiol [Internet]. 2020 [cited 2020 Jun 2];75:2553-66. Available from: http://www.sciencedirect.com/science/article/pii/S0735109720347501

34. Borja MS, Zhao L, Hammerson B, Tang C, Yang R, Carson N, Fernando G, Liu X, Budamagunta MS, Genest J, et al. HDL-apoA-I Exchange: Rapid Detection and Association with Atherosclerosis. PLOS ONE [Internet]. Public Library of Science; 2013 [cited 2020 
medRxiv preprint doi: https://doi.org/10.1101/2020.11.11.20214247; this version posted November 13,2020 . The copyright holder for this preprint (which was not certified by peer review) is the author/funder, who has granted medRxiv a license to display the preprint in It is made available under a CC-BY-NC-ND 4.0 International license .

Apr 30];8:e71541. Available from:

https://journals.plos.org/plosone/article?id=10.1371/journal.pone.0071541

35. Ottestad IO, Halvorsen B, Balstad TR, Otterdal K, Borge GI, Brosstad F, Myhre AM, Ose L, Nenseter MS, Holven KB. Triglyceride-rich HDL3 from patients with familial hypercholesterolemia are less able to inhibit cytokine release or to promote cholesterol efflux. J Nutr. 2006;136:877-81.

36. Soria-Florido MT, Schröder H, Grau M, Fitó M, Lassale C. High density lipoprotein functionality and cardiovascular events and mortality: A systematic review and metaanalysis. Atherosclerosis [Internet]. 2020 [cited 2020 May 11]; Available from: http://www.sciencedirect.com/science/article/pii/S0021915020302252

37. Bielicki JK, Forte TM, McCall MR. Minimally oxidized LDL is a potent inhibitor of lecithin:cholesterol acyltransferase activity. J Lipid Res. 1996;37:1012-21.

38. Cedo L, Metso J, Santos D, García-León A, Plana N, Sabate-Soler S, Rotllan N, RivasUrbina A, Mendez-Lara KA, Tondo M, et al. LDL Receptor Regulates the Reverse Transport of Macrophage-Derived Unesterified Cholesterol via Concerted Action of the HDL-LDL Axis: Insight from Mouse Models. Circ Res. 2020;

39. Cedó L, Plana N, Metso J, Lee-Rueckert M, Sanchez-Quesada JL, Kovanen PT, Jauhiainen M, Masana L, Escolà-Gil JC, Blanco-Vaca F. Altered HDL Remodeling and Functionality in Familial Hypercholesterolemia. J Am Coll Cardiol. 2018;71:466-8.

40. Frayn KN, Evans RD. Human Metabolism: A regulatory Perspective (4th ed). Oxford: John Wiley \& Sons; 2019. 
medRxiv preprint doi: https://doi.org/10.1101/2020.11.11.20214247; this version posted November 13, 2020. The copyright holder for this preprint (which was not certified by peer review) is the author/funder, who has granted medRxiv a license to display the preprint in It is made available under a CC-BY-NC-ND 4.0 International license .

41. Kainulainen H, Hulmi JJ, Kujala UM. Potential Role of Branched-Chain Amino Acid Catabolism in Regulating Fat Oxidation. Exerc Sport Sci Rev [Internet]. 2013 [cited 2020 Aug 4];41:194-200. Available from: https://journals.Iww.com/acsmessr/Fulltext/2013/10000/Potential_Role_of_Branched_Chain_Amino_Acid.3.aspx

42. Defesche JC, Gidding SS, Harada-Shiba M, Hegele RA, Santos RD, Wierzbicki AS. Familial hypercholesterolaemia. Nat Rev Dis Primer [Internet]. 2017 [cited 2020 May

29];3:17093. Available from: http://www.nature.com/articles/nrdp201793 
medRxiv preprint doi: https://doi.org/10.1101/2020.11.11.20214247; this version posted November 13, 2020. The copyright holder for this preprint (which was not certified by peer review) is the author/funder, who has granted medRxiv a license to display the preprint in It is made available under a CC-BY-NC-ND 4.0 International license .

\section{Figure legends}

Figure 1
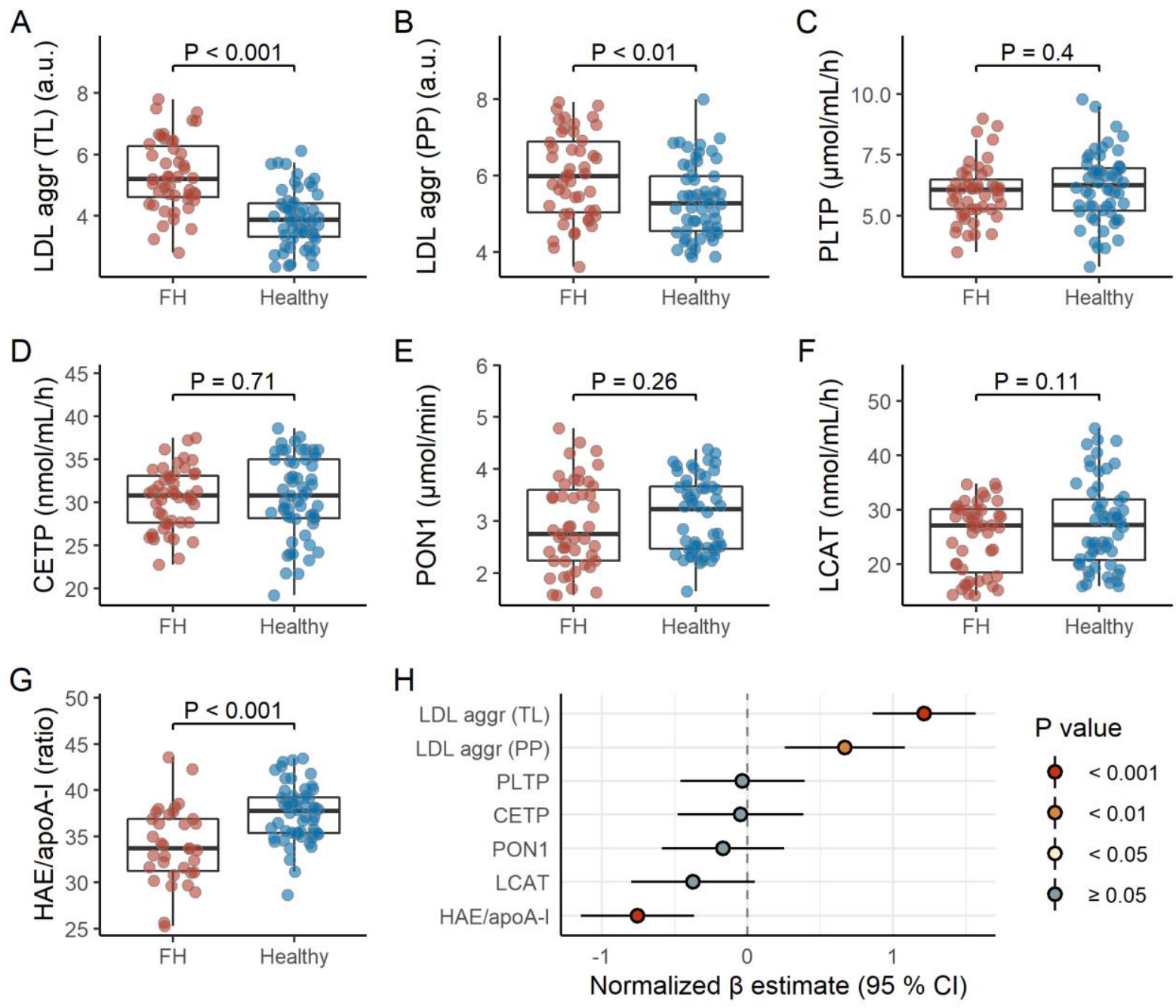

Figure 1. FH children display higher LDL aggregation and lower HAE/apoA-I ratio. Panels A-G shows raw data distributions for LDL aggregation (total load or per particle), PLTP, CEPT, PON1, LCAT, and HAE/apoA-I for FH children $(n=47)$ and healthy children $(n=56)$. Note that the LDL aggregation (total load and per particle) and PON1 variables are $\log _{e}$ transformed. $P$ values are based on an Independent Samples T test. See Table S3 for the summary statistics corresponding to these biomarkers for FH children and healthy children separate, and both groups combined. The forest plot (panel $\mathrm{H}$ ) shows the estimated difference between $\mathrm{FH}$ 
medRxiv preprint doi: https://doi.org/10.1101/2020.11.11.20214247; this version posted November 13, 2020. The copyright holder for this preprint (which was not certified by peer review) is the author/funder, who has granted medRxiv a license to display the preprint in It is made available under a CC-BY-NC-ND 4.0 International license .

children and healthy children, represented by $\beta$ regression coefficients $( \pm 95 \%$ confidence intervals). Coefficients on the right side of the zero-line indicate higher level in FH children, and opposite for the left side. All biomarkers were normalized prior to modeling (mean =0, standard deviation = 1); the models are adjusted for age, sex, and BMI z score.

Abbreviations: aggr, aggregation; apoA-I, apolipoprotein A-I; CETP, cholesteryl ester transfer protein; HAE, HDL-apoA-I exchange; HDL, high-density lipoprotein; LCAT, lecithin-cholesterol acyltransferase; LDL, low-density lipoprotein; PLTP, phospholipid transfer protein; PON1, paraoxonase-1; PP, per particle; TL, total load. 
medRxiv preprint doi: https://doi.org/10.1101/2020.11.11.20214247; this version posted November 13,2020 . The copyright holder for this preprint (which was not certified by peer review) is the author/funder, who has granted medRxiv a license to display the preprint in It is made available under a CC-BY-NC-ND 4.0 International license.

Figure 2

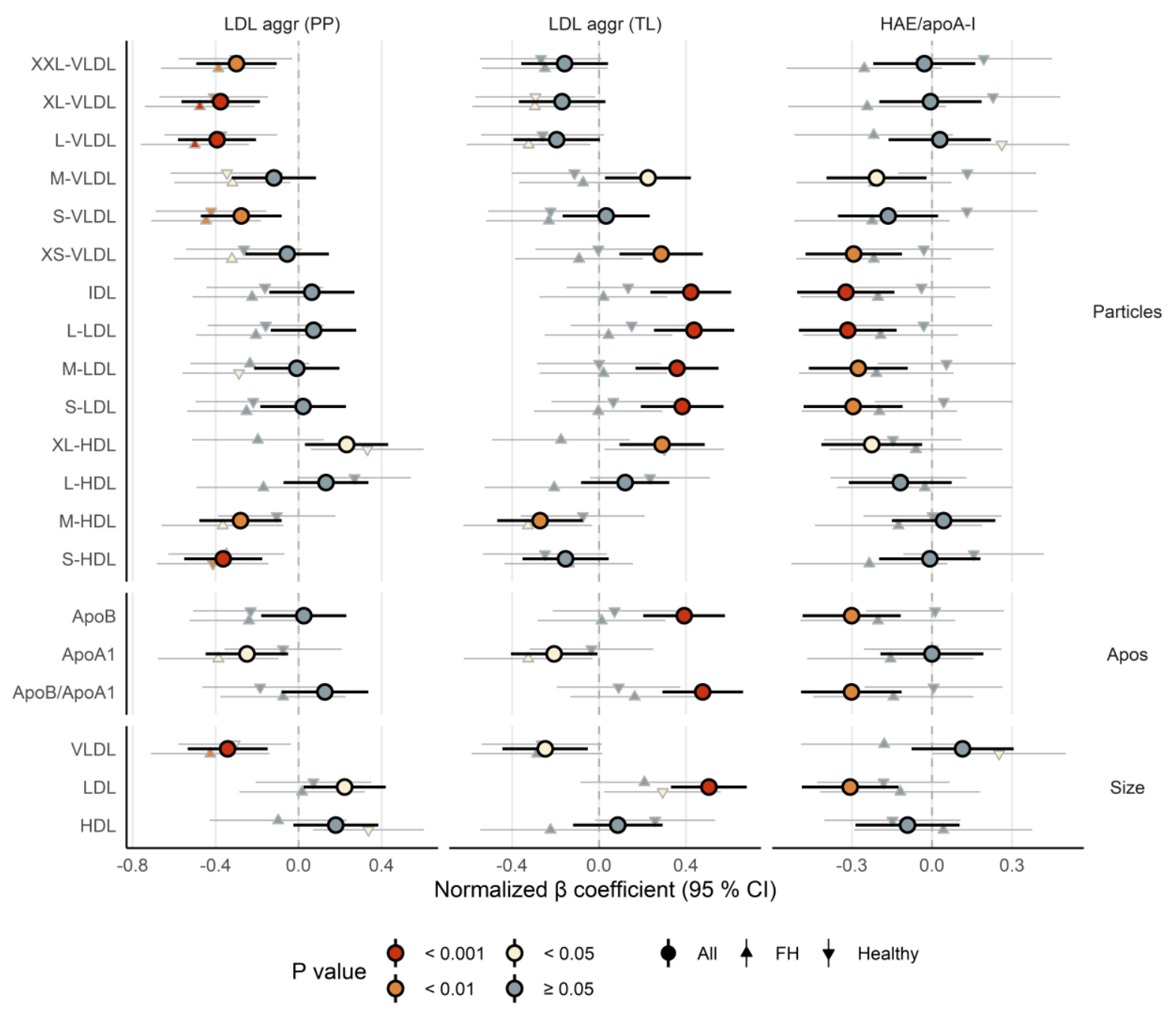

Figure 2. LDL aggregation and HAE/apoA-I ratio associate with lipoprotein particles,

apolipoproteins, and particle size. The forest plot shows the association between lipoprotein function metrics (LDL aggregation (per particle or total load) or HAE/apoA-I ratio) and a subset of NMR-derived metrics (lipoprotein particles, apolipoproteins and lipoprotein particle size, for the major lipoprotein subclasses), represented by $\beta$ regression coefficients ( $\pm 95 \%$ confidence intervals). The symbols show the associations for all children combined (larger circles), FH children only (upward pointing triangles), and healthy children only (downward pointing triangles). Coefficients on the right side of the zero-line indicate a 
medRxiv preprint doi: https://doi.org/10.1101/2020.11.11.20214247; this version posted November 13, 2020. The copyright holder for this preprint (which was not certified by peer review) is the author/funder, who has granted medRxiv a license to display the preprint in It is made available under a CC-BY-NC-ND 4.0 International license .

positive association, and opposite for the left side. Lipoprotein function metrics and all NMR metrics were normalized prior to modeling ( mean $=0$, standard deviation $=1$ ); the models were adjusted for age, sex, and BMI z score. Abbreviations: aggr, aggregation; apoA-I, apolipoprotein A-I; ApoB, apolipoprotein B; HAE, HDL-apoA-I exchange; HDL, high-density lipoprotein; IDL, intermediate-density lipoprotein; L, large; LDL, low-density lipoprotein; M, medium; PP, per particle; S, small; TL, total load; VLDL, very low-density lipoprotein; XL, very large; XS, very small; XXL, extremely large. 
medRxiv preprint doi: https://doi.org/10.1101/2020.11.11.20214247; this version posted November 13,2020 . The copyright holder for this preprint (which was not certified by peer review) is the author/funder, who has granted medRxiv a license to display the preprint in It is made available under a CC-BY-NC-ND 4.0 International license.

Figure 3

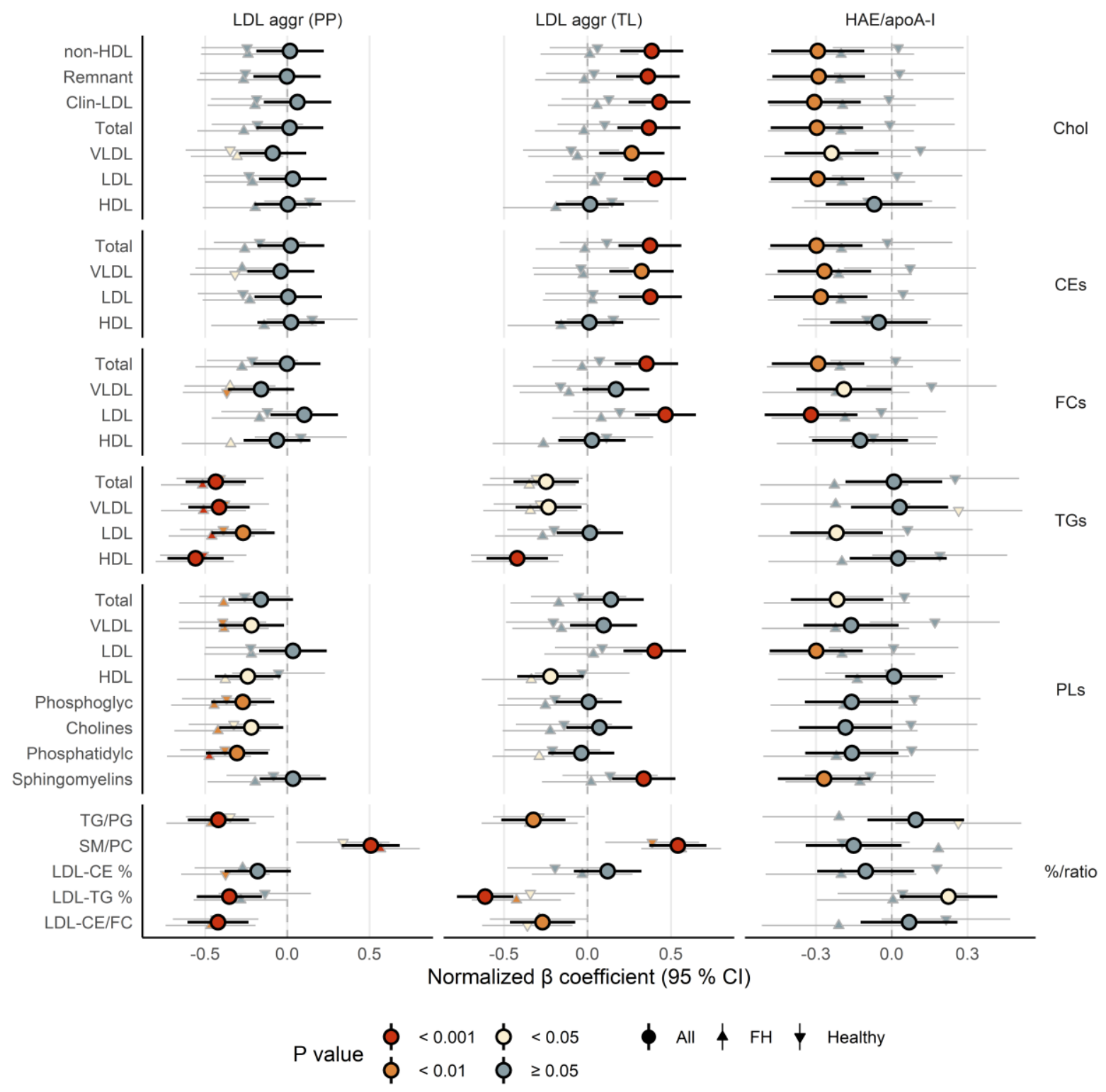

Figure 3. LDL aggregation and HAE/apoA-I ratio associate with total cholesterol, cholesterol esters, free cholesterol, triglycerides, and phospholipids. The forest plot shows the association between lipoprotein function metrics (LDL aggregation (per particle or total load) or HAE/apoA-I ratio) and a subset of NMR-derived metrics (total cholesterol, cholesterol esters, free cholesterol, triglycerides, and phospholipids, for the major lipoprotein subclasses). Interpretation similar as for Figure 2. Abbreviations: aggr, aggregation; apoA-I, 
medRxiv preprint doi: https://doi.org/10.1101/2020.11.11.20214247; this version posted November 13, 2020. The copyright holder for this preprint (which was not certified by peer review) is the author/funder, who has granted medRxiv a license to display the preprint in It is made available under a CC-BY-NC-ND 4.0 International license .

apolipoprotein A-I; ApoB, apolipoprotein B; CEs, cholesterol esters; Chol, cholesterol; Clin, clinical; FCs, free cholesterol; HAE, HDL-apoA-I exchange; HDL, high-density lipoprotein; IDL, intermediate-density lipoprotein; LDL, low-density lipoprotein; Phosphatidylc, phosphatidylcholines; Phosphoglyc, total phosphoglycerides; PLs, phospholipids; PP, per particle; SM/PC, sphingomyelin/phosphatidylcholine ratio; TGs, triglycerides; TG/PG, triglyceride/phophoglycerides ratio; TL, total load; VLDL, very low-density lipoprotein. 
medRxiv preprint doi: https://doi.org/10.1101/2020.11.11.20214247; this version posted November 13,2020 . The copyright holder for this preprint (which was not certified by peer review) is the author/funder, who has granted medRxiv a license to display the preprint in It is made available under a CC-BY-NC-ND 4.0 International license .

Figure 4

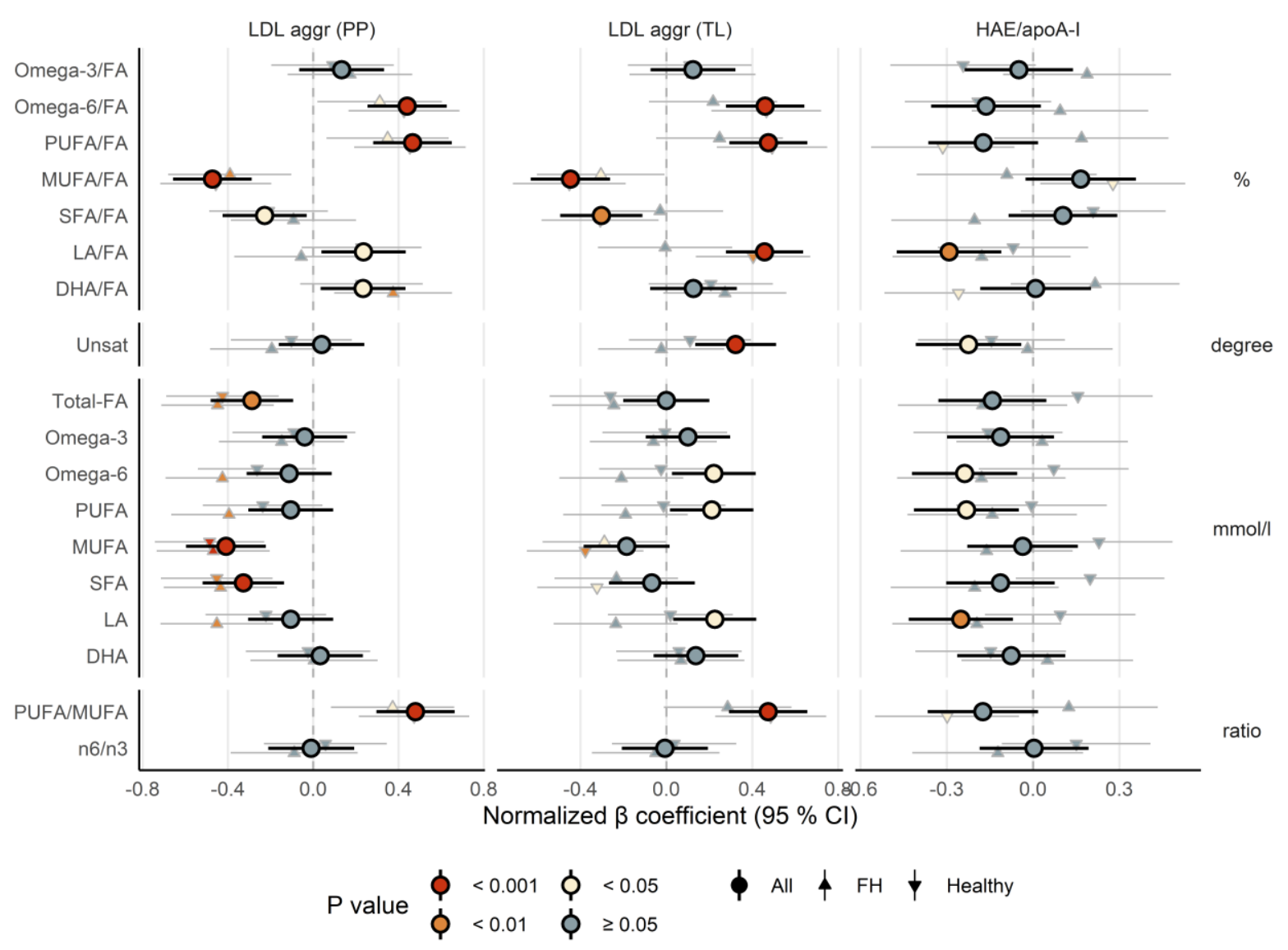

Figure 4. LDL aggregation and HAE/apoA-I ratio associate with fatty acids. The forest plot

shows the association between lipoprotein function metrics (LDL aggregation (per particle or total load) or HAE/apoA-I ratio) and a subset of NMR-derived metrics (fatty acids, in absolute or relative amounts). Interpretation similar as for Figure 2. Abbreviations: aggr, aggregation; apoA-I, apolipoprotein A-I; DHA, docosahexaenoic acid; FA, fatty acids; HAE, HDL-apoA-I exchange; HDL, high-density lipoprotein; LA, linoleic acid; LDL, low-density lipoprotein; $\mathrm{mmol} / \mathrm{L}$, absolute concentration; MUFA, monounsaturated fatty acids; n6, omega-6 fatty acids; n3, omega-3 fatty acids; PP, per particle; PUFA, polyunsaturated fatty acids; SFA, saturated fatty acids; TL, total load; \%, relative level (percentage of total fatty acids). 
medRxiv preprint doi: https://doi.org/10.1101/2020.11.11.20214247; this version posted November 13,2020 . The copyright holder for this preprint (which was not certified by peer review) is the author/funder, who has granted medRxiv a license to display the preprint in It is made available under a CC-BY-NC-ND 4.0 International license .

Figure 5

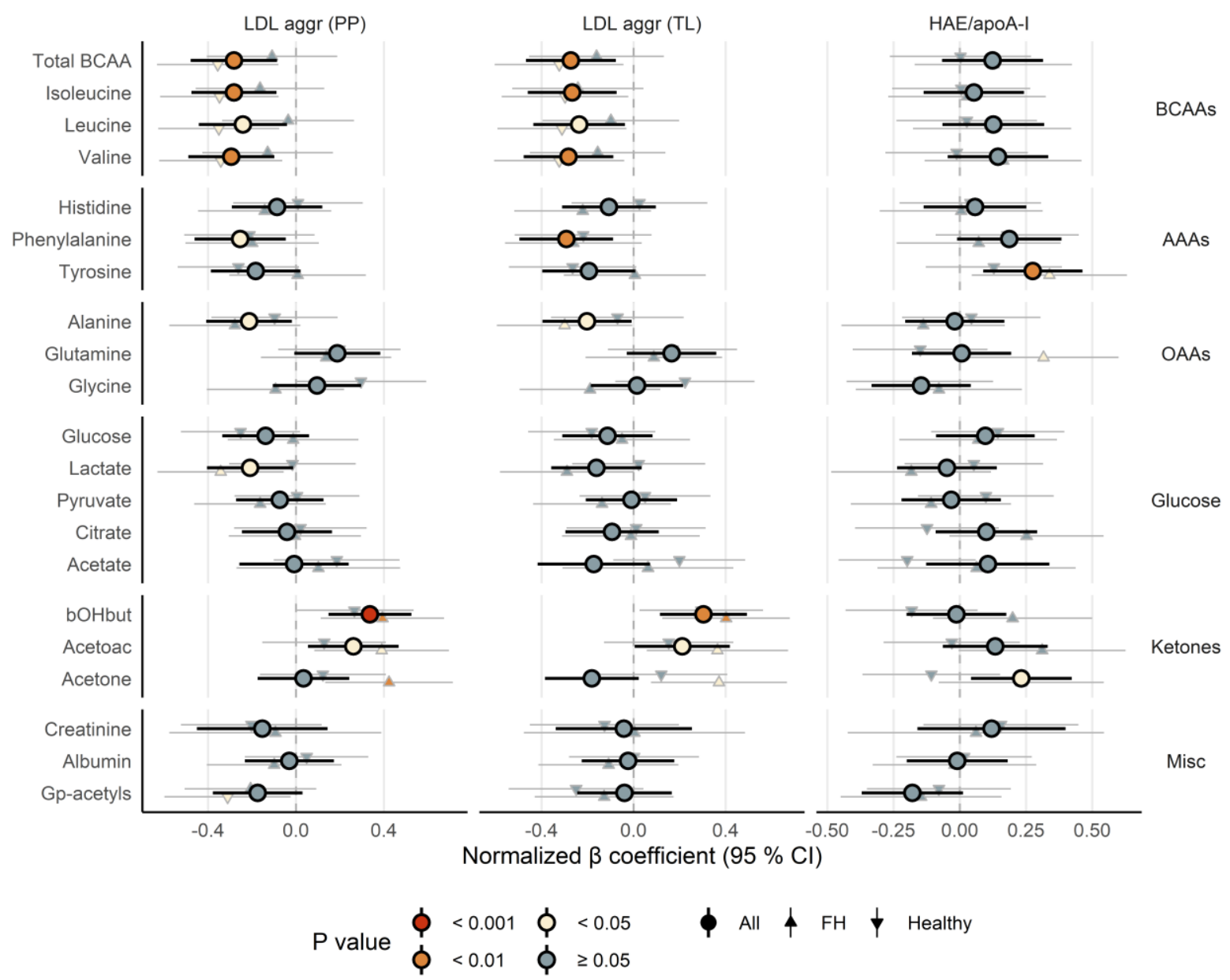

Figure 5. LDL aggregation and HAE/apoA-I ratio associate with amino acids, glucose

metabolites, ketone bodies and other biomarkers. The forest plot shows the association between lipoprotein function metrics (LDL aggregation (per particle or total load) or HAE/apoA-I ratio) and a subset of NMR-derived metrics (amino acids, glucose metabolites, ketone bodies and other biomarkers). Interpretation similar as for Figure 2. Abbreviations: AAAs, aromatic amino acids; aggr, aggregation; apoA-I, apolipoprotein A-I; arom, aromatic; BCAAs, branched-chain amino acids; bOHbut, beta-hydroxybutyric acid; cap, capacity; Gpacetyls, glycoprotein acetyls; HAE, HDL-apoA-I exchange; HDL, high-density lipoprotein; LDL, low-density lipoprotein; OAAs, other amino acids. 
Figure 6

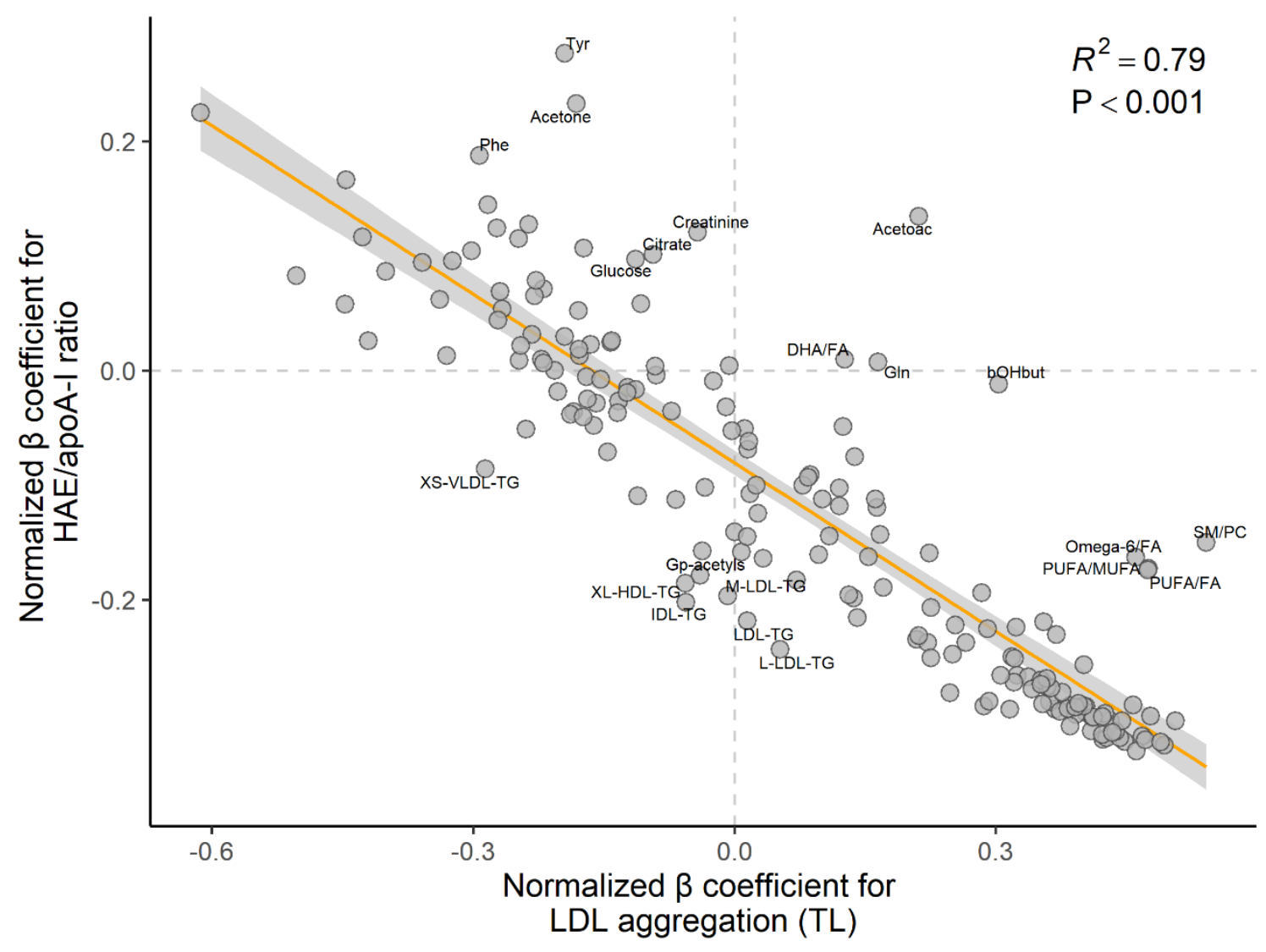

Figure 6. Associations between lipoprotein function metrics and NMR-derived metrics generally go in the opposite direction for LDL aggregation and HAE/apoA-I ratio. The scatterplot shows the inverse relationship between $\beta$ regression coefficients for all NMRderived metrics, for associations with LDL aggregation (TL) (x-axis) and associations with HAE/apoA-I ratio (y-axis). Note that each circle corresponds to a variable shown in Figures 2 to 5 (models for all children). Coefficients on the right side of the vertical zero-line indicate a positive association with LDL aggregation (TL), and opposite for the left side; similarly, coefficients above the horizontal zero-line indicate a positive association with HAE/apoA-I ratio, and opposite below. Annotated variables are those with standardized residuals above 1.5 (absolute value), which means they are more than 1.5 standard deviations away from the orange least-squares regression line. Lipoprotein function metrics and all NMR metrics were 
medRxiv preprint doi: https://doi.org/10.1101/2020.11.11.20214247; this version posted November 13, 2020. The copyright holder for this preprint (which was not certified by peer review) is the author/funder, who has granted medRxiv a license to display the preprint in It is made available under a CC-BY-NC-ND 4.0 International license .

normalized prior to modeling (mean $=0$, standard deviation $=1$ ); the models were adjusted for age, sex, and BMI z score. Abbreviations: Acetoac, acetoacetate; apoA-I, apolipoprotein A-I; bOHbut, beta-hydroxybutyric acid; DHA, docosahexaenoic acid; FA, fatty acids; GIn, glutamine; Gp-acetyls, glycoprotein acetyls; HAE, HDL-apoA-I exchange; HDL, high-density lipoprotein; IDL, intermediate-density lipoprotein; L, large; LDL, low-density lipoprotein; M, medium; MUFA, monounsaturated fatty acids; P, P value; Phe, phenylalanine; PUFA, polyunsaturated fatty acids; $R^{2}$, explained variance; TG, triglycerides; Tyr, tyrosine; VLDL, very low-density lipoprotein; XL, very large; XS, very small. 